\title{
Ken Dedes Profile Description in Expert Perspective
}

\author{
Lutfiati D. ${ }^{1}{ }^{*}$ Alrianingrum S. ${ }^{2}$, Puspitorini A. ${ }^{3}$, Insani M. ${ }^{4}$ Muttimatul Faidah ${ }^{5}$ \\ ${ }^{1}$ Home Economic Education, Facullty of Engineering, Unesa \\ ${ }^{2}$ History Department, Social and Humaniora Faculty, Unesa \\ ${ }^{3}$ Cosmetology Department, Facullty of Engineering, Unesa \\ ${ }^{4}$ Cosmetology Department, Facullty of Engineering, Unesa \\ ${ }^{5}$ Cosmetology Department, Facullty of Engineering, Unesa \\ *Corresponding author. Email: dewilutfiati@unesa.ac.id
}

\begin{abstract}
The beauty of Ken Dedes, who was the consort of Ken Arok from the Raja of Singhasari Kingdom, was famous throughout the archipelago. This research was conducted to explore information about the depiction of the figure of Ken Dedes. With a qualitative research approach, data were collected using interviews, observation and documentation study. The resource persons were selected by archaeologists, historians, librarians, and ancient Javanese fiber experts. To test the validity of the data using the triangulation method including Source Triangulation and Technique Triangulation. The results showed that Ken Dedes is a figure who has physical beauty and has perfect behavior. The statue Prajnaparamitha as a symbol of Kendedes has a beautiful face and a beautiful body, staying up as one of the most beautiful statues in Java. Ken Dedes is a depiction of an ideal woman during the Hindu-Buddhist kingdom. Ken Dedes is also called the woman "Stri Nareswari" who is believed to have given birth to rulers in Java. Ken Dedes has a perfect or civilized beauty. In addition, Ken Dedes is known as a figure who has perfect behavior because Ken Dedes has mastered the knowledge of Karma Amamadani or commonly called the 10 ways of goodness.
\end{abstract}

Keywords: Ken Dedes, Depiction, Beauty, Behavior

\section{INTRODUCTION}

Ken Dedes is a beautiful consort who is the wife of the king of Singosari Kingdom, Ken Arok. Raja Ken Arok has 2 wives namely Ken Umang and Ken Dedes, but what is widely known by the wider community is Ken Dedes. Beauty Ken Dedes is famous in all corners of the archipelago. According to Indradjaja (2017: 111), the view of the Javanese people regarding the ideal of beautyrepresentation is on the statue of Prajnaparamita which is an embodiment of Ken Dedes. The Prajnaparamitha relic depicted a woman with a calm face sitting in the position of Dharmacakramudra and there is a halo on the back of the head which indicates that Ken Dedes is a Goddess. With various assumptions from many people, here will be revealed how the actual perspective of the figure of Ken Dedes in the view of experts.

Indonesia has great ancestors who are actually very interesting to study and can be taken on the positive side such as behavior, leadership, and wisdom. But unfortunately, a lot of history and culture still does not get the attention of the community and began to be forgotten by the community, especially the next generation who should help preserve it from now on. Because of the lack of awareness of the importance of preserving history and culture, also because of the entry of modern cultures from the outside. Historical relics in the form of ancient objects are damaged and some have been taken by the Dutch during the Indonesian colonial era is also a reason why the existing culture received less attention. Many ancient objects were damaged because they were not treated and the inclusion of Islam in Java did not allow objects that resembled living things, so many statues were removed from the head. Therefore, it is very necessary to be reintroduced to society, especially to the nation's next generations.

\section{II.RESEARCH METHOD}

This study uses a qualitative approach with research results in the form of description. The descriptive approach is the data collected in the form of words, images, and not numbers so that this time the research is carried out a search, collecting data from speakers in the form of words and images.

The object in this study is the depiction of the figure of Ken Dedes. So that the object in this study can be known after conducting interviews with several sources and observing the statue of Prajnaparamitha, which is an embodiment of Ken Dedes and documentation studies. Data collection techniques used in this study include:

a. Interview: This is a technique to get information about the figure of Ken Dedes in the past.

b. Observation: Is a technique of direct observation to look directly at the object you want to examine. The observed objects are usually behavioral, human actions, natural phenomena, work processes, and 
small respondents. In this research, the object of observation is the depiction of figures in the past.

c. Documentation Study: is a data collection technique that aims to obtain data directly from written sources, archives, and other documents related to research.

Data analysis in this study is used to find and compile data and facts about beauty treatments conducted by Ken Dedes that will be obtained from trusted sources until the achievement of research objectives or until the data collected is saturated. The following data analysis used in this study are:

1. Data Reduction: It is the activity of summarizing, selecting and grouping key and important data, then looking for themes and patterns from the data to make it easier for researchers to carry out the next stage of research.

2. Data Presentation: Displaying data in qualitative research can be made in the form of brief descriptions, charts, relationships between categories, flowcharts, and the like. The most frequently used in presenting data in qualitative research is narrative text.

3. Withdrawal of Conclusions: Conclusions in qualitative research may answer the problem formulation that was set from the beginning but also may not.

The conclusion is a finding in the form of a description or picture of an object that was previously unclear or vague and after examination of the object becomes clear.

To test the validity of the data using several techniques including:

\section{Triangulation}

a. Source Triangulation: Used to test credibility by checking data obtained from several sources.

b. Technical Triangulation: Used to test the credibility of the data by checking the data obtained from the three data collection techniques, namely interviews, observation, and documentation.

2. Member check: the process of checking the data obtained from sources who aims to find out how far the data obtained in accordance with what is given by the resource persons.

\section{RESULT}

\section{Data Exposure}

After researching the East Java Cultural Heritage Preservation Agency, the figure of Ken Dedes as described by archaeologists at BPCB East Java is as follows:
"Ken Dedes is the figure of Tara who is the perfection of a woman. When viewed from the arc, Ken Dedes is a beautiful woman with an ideal body with beautiful curves. Having a beautiful face with a sharp nose and beautiful lips. According to the story of Ken Dedes, he has bright, yellow skin.

Then the explanation from the librarian at the East Java Cultural Heritage Preservation Agency about the figure of Ken Dedes is as follows:

"Ken Dedes is a figure who is famous for her beauty. Ken Dedes beauty is mentioned in many books and ancient books. Ken Dedes' beauty is also proven because the statue is one of the most beautiful statues in Java. After all, it is included in the category of Javanese women's beauty, which has beautiful curves.

After that the research was carried out at the Cultural Value Preservation Hall D.I.Y. regarding the figure of Ken Dedes as revealed by ancient fiber interpreters is as follows:

"Ken Dedes is famous for his beauty which is also mentioned in ancient fibers. Ken Dedes Has the ideal body that can be seen from the arc ".

Then carried out research in the Department of Tourism and Culture about the figure of Ken Dedes as revealed by the Head of History and Culture in the Disparbud Malang Regency is as follows:

"Ken Dedes is a figure who has perfect beauty".

In addition, the historian Singhasari also provided further explanation regarding the figure of Ken Dedes as follows:

"The true beauty that Ken Dedes has is the beauty of his personality. Ken Dedes is also a person who does not think worldly because Ken dedes great at the hermitage. Ken Dedes won the title of woman (Prajna Paramitha). Ken Dedes is a figure of "Stri Nareswari" who gave birth to the rulers in the Land of Java. All good things that are inherent in Ken Dedes cannot be separated from because Ken Dedes mastered the knowledge of "Karma Amamadani".

"The statue of Ken Dedes has a head or circumference on the head which indicates that ken Dedes has a high degree". 


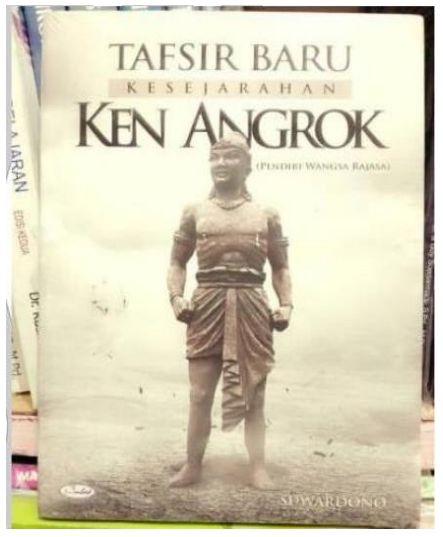

Image 1. Book with Karma Amanadani

The informant's information above is also in accordance with the results of the documentation study in the book entitled "The New Interpretation of Ken Angrok's History" stated that Ken Dedes has mastered this knowledge and explained the points of the "Karma Amamadani" science. In the interview about the figure of Ken Dedes, information was obtained from 5 sources, namely Archeologist BPCB East Java, Librarian BPCB East Java, Expert Interpreter of Ancient Fiber BPNB D.I.Y. Yogyakarta, Head of the History and Culture Section of Disparbud Kab. Malang, and historians of Singhasari.

\section{DISCUSSION}

Based on the interview results obtained data that indeed Ken Dedes is the figure of empress Singhasari who is beautiful in terms of physical as well as in terms of behavior. Until Ken Dedes got various names ranging from Prajnaparamitha which means a woman who is wise and behaves perfectly. Many who justify the perfection of physical beauty from Ken Dedes such as having skinny yellow skin, beautiful face and ideal body with beautiful curves. mentioned if his physical beauty is not perfect it is impossible Tunggul Ametung to want to kidnap him and if Ken dedes are not beautiful it is impossible for Ken arok fell in love to think of killing Ken Dedes husband so he could marry Ken Dedes apart from Ken arok knowing if ken dedes was a woman who "Stri Nareswari" who will give birth to big kings in the Land of Java.

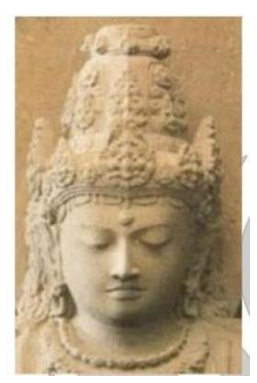

When viewed from the statue of "Prajnaparamitha" Ken Dedes has a beautiful face with wide eyes, a sharp nose, raised eyebrows, and thin lips. At the relic, Ken Dedes has an oval face frame. Oval face shape is a face shape that until now was considered Proportional. According to Soekarno (2013: 189), a proportional face is when drawn a line will resemble the shape of a heart, meaning that the cheekbones are parallel to the eyebrows and tapered at the chin. Position the eyes vertically right at a distance of about $1 / 3$ of the eyebrows to the nose. The distance from the hairline to the eyebrows, eyebrows to the nose, and nose to the chin are the same. The location of the lips is $1 / 3$ from the nose to the chin.

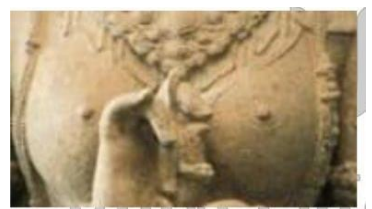

Image 3. Chest section of Prajnaparamitha relic

When viewed from the shape of her breasts, Ken Dedes has the shape of breasts that are considered beautiful like ivory coconut. Called to resemble ivory coconut because of its tight round shape and its nipples facing forward. It also illustrates that Ken Dedes cared for his body so it had a beautiful breast shape.

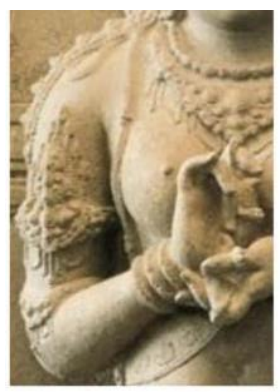

Image 4. Arm section of Prajnaparamitha relic

Judging from the shape of Ken Dedes' arm on the statue "Prajnaparamitha" has a proportional arm and not sagging at all. According to Sukarno (2013: 189), proportional arms are those that have a length ranging from shoulders to hips and perpendicular to the shoulder. It was also seen that Ken Dedes took care of his body because he had tight arms. It can be seen that Ken Dedes has a balanced weight can also be seen from the proportional shape of his arms.

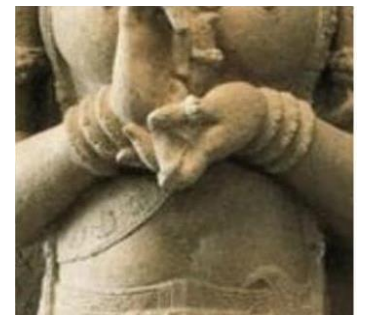

Image 5. Abdomen section of Prajnaparamitha relic

Image 2. Face section of Prajnaparamitha relic 
In the abdomen that can be seen from the statue "Prajnaparamitha" has a fairly slim waist and a belly that does not sag. Waist shape like this can be categorized as a beautiful waist. Judging from the shape of the waist and abdomen, Ken Dedes takes good care of hisbody.

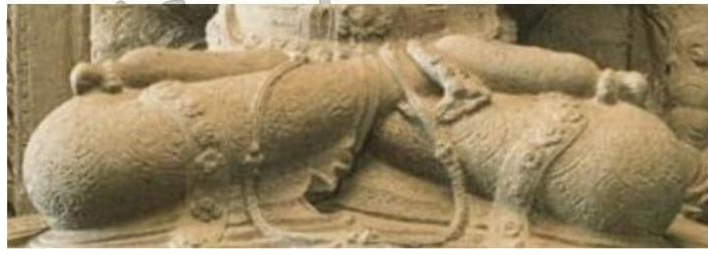

Image 5. Leg section of Prajnaparamitha relic

The foot image above shows that Ken Dedes has a fairly long leg because he has long calves. The shape of the legs is also beautiful because they are not too big and not too small. In accordance with the designation of beautiful feet like palm leaves

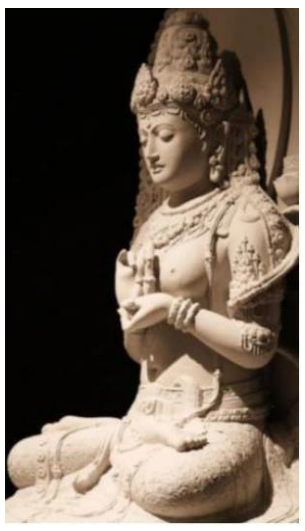

Image 7. Lateral view of Prajnaparamitha relic

Based on the interview results obtained data that Ken Dedes is a royal consort of Singhasari who is beautiful in terms of physical as well as in terms of behavior. Viewed in terms of physical according to design science that the size of a woman's body proportion of at least $7 \mathrm{x}$ the height of the head, and Ken Dedes has a height that is $7 \mathrm{x}$ the height of the head. Means Ken Dedes can be categorized as an ideal body. Until Ken Dedes got the title starting from "Prajnaparamitha" which means a woman who is wise and behaves perfectly. Many also justify the perfection of the physical beauty of Ken Dedes, such as having yellow skin, a beautiful face, and an ideal body with beautiful curves. Ken Dedes also has perfect behavior because he has mastered the science of "Karma Amamadani" which is 10 paths of kindness that are very difficult for a woman to do. So Ken Dedes is a woman of civilian perfection. Besides having physical beauty he also behaves perfectly. Not wrong if he is very well known from the past until now. Ken Dedes is also called the Goddess Tara or the perfect goddess that can be seen from the arc that raises a halo or a circle on the back of her head.

\section{CONCLUSION}

Ken Dedes is the Goddess of Tara, which means perfection from a woman and gets the title Prajna Paramita which means a woman who has perfection in wisdom, perfect beauty, behaviour, and has a good understanding about 10 ways of goodness

\section{REFERENCES}

Arikunto, Suharsimi. 2013. Prosedur Penelitian. Jakarta: Rineka Cipta.

Bosch, F. 1956. C.C. Berg and ancient Javanese history. In: Bijdragen tot de Taal-, Land- en Volkenkunde 112 (1956), no: 1, Leiden, 124

Firmansyah, D., Yahmin. Ken Angrok Pendiri Wangsa Rajasa. E-Jurnal Budi Utomo Malang.

http://ejurnal.budiutomomalang.ac.id/index .php/maharsi/article/download/555/369/, diakses tanggal 24 Februari 2020.

J. Ras. 1987.The genesis of the Babad Tanah Jawi; Origin and function of the Javanese court chronicle. In: Bijdragen tot de Taal-, Landen Volkenkunde 143, no: 2/3, Leiden, 343356.

Junianto, Lestari, R.N.S., Subadyo A.T. 2017. Site Setup Patirtan Watugede Singosari, Malang, Indonesia As a Spiritual Tourism Object. International Conference "Sustainable Development Goals 2030 Challenges and Its Solutions". 11-12 August 2017. Hal. 544-553.

Kasdi, Aminudin.2005.Memahami Sejarah. Surabaya:Unesa University Press.

Kempers, A.J.

Bernet. 1959. Ancient Indonesian A $r t$. Cambridge: Harvard University Press.

Indradjaja, Agustijanto. 2005. Penggambaran Ideal Perempuan Jawa pada Masa HinduBudha. Purbawidya. Vol. 6: hal 108-112.

Moleong, Lexy

J. 2017. Metode Penelitian Kualitatif

Bandung: Remaja Rosdakarya.

Mulyadi, Lalu, Hutabarat J. Harisman, A. 2016. Relief and Statue SINGOSARI TEMPLE. CV. Dream Litera Buana, Malang.

Munandar, A.A. 2011. Menafsirkan Ulang Riwayat Ken Arok dan Ken Dedes dalam Kitab Pararaton. Jurnal Manassa. Vol 1 (1): hal.1-15.

Nasution,Ramadhani.2008. Warisan Masa Lampau Indonesia: Kerajaan Singhasari(12221292 Masehi). Jakarta: Dunia Ilmu 
Putri, R.H. Ken Dedes Perempuan Utama.

https://historia.id/kuno/articles/ken-dedesperempuan-utama- $\mathrm{P} 4 \mathrm{WgV}$, access in 24

February 2020. 